\title{
Competing Against Time: Report of the Governor's Board of Inquiry on the 1989 Loma Prieta Earthquake
}

\author{
George W. Housner, HM.EERI, and Charles C. Thiel, Jr., M.EERI
}

\begin{abstract}
A Board of Inquiry was appointed by the Governor of California to investigate the 1989 Loma Prieta Earthquake. The formation of the Board was prompted by earthquake damage to bridges and freeway structures and the desire to know not only what happened, but how to prevent such destruction in future earthquakes. The Board made fifty-two specific findings and eight recommendations. They identified three essential challenges that must be addressed by the citizens of California, if they expect a future adequately safe from earthquakes: 1) ensure that earthquake risks posed by new construction are acceptable; 2) identify and correct unacceptable seismic safety conditions in existing structures, and; 3) develop and implement actions that foster the rapid, effective, and economic response to and recovery from damaging earthquakes The Loma Prieta earthquake should be considered a clear and powerful warning to the people of California. Although progress has been made during the past two decades in reducing earthquake risks, much more could have been done, and awaits doing. More aggressive efforts to mitigate the consequences of future, certain earthquakes are needed if their disastrous potential is to be minimized and one of the most fundamental of responsibilities of government is to be fulfilled-to provide for the public safety. The Governor signed an Executive Order implementing the principal recommendations of the Board that may prove to be the most significant step to improve seismic safety within the State taken in the last several decades. It establishes the policy that all state owned and operated structures are to be seismically safe and that important structures are to maintain their function after earthquakes.
\end{abstract}

The Governor of California signed an Executive Order on June 2, 1990 that may prove to be the most significant step to improve seismic safety taken by the State in the last several decades. Executive Order 86-90 sets for the first time the policy that all state owned and operated structures are to be seismically safe and that important structures are to maintain their function after earthquakes [1]. This is a marked departure from responses to past earthquakes where actions tended to focus on the type of facility that failed. The full text of the Order is reproduced in Table 1 . The Order was a direct consequence of the recommendations and findings contained in the report of the Board of Inquiry on the Loma Prieta Earthquake of 1989 The language is simple and direct and the actions required specific and directed. For those unfamiliar with the workings of government, it is usual that governmental agencies are exempt from the building codes and standards that they enforce on others, and it is usual that the standards they use are self-administered. The Governor has required the Department of Transportation in particular and all other state agencies in general to use generally accepted

GWH-California Institute of Technology, Pasadena, California

CCT-Consulting Engineer, Piedmont, California 
Table 1. Text of Executive Department State of California Executive Order D86-90 signed on June 2, 1990 in response to the Report of the Board of Inquiry on the Loma Prieta Earthquake of 1989 report and recommendations.

WHEREAS, on October 17, 1989 a major earthquake occurred in Northern California, causing deaths, injuries, and widespread damage to transportation facilities and other structures; and

WHEREAS, an independent Board of Inquiry was formed in November 1989 to investigate the reasons for the collapse of transportation structures and to recommend actions to reduce the danger of tragic structural failures in future earthquakes; and

WHEREAS, the Board of Inquiry found that there is a high probability that one or more major earthquakes will strike heavily populated areas in Northern and Southern California in the future; and

WHEREAS, California's state of earthquake readiness needs improvement to better protect the public safety and our economy from potentially serious impacts of future earthquakes;

NOW, THEREFORE, I, GEORGE DEUKMEJIAN, Governor of the State of California, by virtue of the power and authority vested in me by the Constitution and Statues of the State of California, do hereby issue this order, to become effective immediately:

1. It is the policy of the State of California that seismic safety shall be given priority consideration in the allocation of resources for transportation construction projects, and in the design and construction of all state structures, including transportation structures and public buildings.

2. The Director of the Department of Transportation shall prepare a detailed action plan to ensure that all transportation structures maintained by the State are safe from collapse in the event of an earthquake and that vital transportation links are designed to maintain their function following an earthquake. The plan should include a priority listing of transportation structures which will be scheduled for seismic retrofit. The Director shall transmit this action plan to the Governor by August 31, 1990.

3. The Director of the Department of Transportation shall establish a formal process whereby the Department seeks and obtains the advise of external experts in establishing seismic safety policies, standards, and technical practices; and for seismic safety reviews of plans for construction or retrofit of complex structures. The Director shall transmit a summary of this process to the Governor by August 31, 1990.

4. The Director of the Department of Transportation shall assign a high priority to development of a program of basic and problem-focused research on earthquake engineering issues, to include comprehensive earthquake vulnerability evaluations of important transportation structures and a program for placing seismic activity monitoring instruments on transportation structures. The Director shall transmit a description of the research program to the Governor by August 31, 1990.

5. Local transportation agencies and districts are encouraged to review the findings and recommendations of the Board of Inquiry on the 1989 Loma Prieta Earthquake and to adopt policies, goals, and actions similar to those proposed for Caltrans. 
Table 1. (cont.)

6. The Director of the Department of General Services shall prepare a detailed action plan to ensure that all facilities maintained or operated by the State are safe from significant failure in the event of an earthquake and that important structures are designed to maintain their function following an earthquake. The plan should include a prionity listing of facilities which will be scheduled for seismic retrofit. The plan shall further propose measures by which the state agencies construction new facilities or retrofitting existing facilities would:

a. be governed by the provisions of a generally accepted earthquake resistant code for new construction;

b. secure structural safety review and approval from the Office of the State Architect;

c. seek independent review of structural and engineering plans and details for those projects which employ new or unique construction technologies; and

d. have independent inspections of construction to insure compliance with plans and specifications.

The Director shall transmit the plan to the Governor by August 31, 1990.

7. The Department of General Services shall, when negotiating leases of facilities for use by state employees or the public, consider the seismic condition of the facilities and shall initiate leases only for those facilities which demonstrate adequate seismic safety.

8. The Seismic Safety Commission shall review state agencies' actions in response to this executive order and the recommendations of the final report of the Board of Inquiry and provide a report to the Governor on the adequacy and status of actions taken by December 1 1990.

9. The University of Califomia and the Califomia State University shall give priority consideration to seismic safety in the allocation of resources available for construction projects. The University of California and the California State University shall prepare and transmit to the Governor by August 31, 1990 a description of their plans to increase seismic safety at facilities which they maintain or operate.

IN WITNESS WHEREOF I have hereunto set my hand and caused the Great Seal of the State of California to be affixed this 2nd day of June 1990.

SEAL

George Deukmejian

Governor of California

ATTEST:

March Fong Eu

Secretary of State 
earthquake resistant codes and to seek external evaluations of compliance. The effect of external scrutiny should not be underestimated as a tool to obtain better seismic design and construction. Implementation of this Executive Order offers the opportunity for substantial improvement in the seismic resistance of both state and private buildings as well as all those other transportation and lifeline structures.

In November 1989 Governor George Deukmejian of California appointed an Independent Board of Inquiry to report on the October 17, 1989 Loma Prieta earthquake. The formation of the Board was prompted by earthquake damage to bridges and freeway structures and the desire to know not only what happened, but how to prevent such destruction in future earthquakes. The Governor charged the Board with reporting on the causes of damage and what implications these findings have on the California highway system [2]. The Board issued its report on May 31, 1990 [3]. This paper reviews the findings and recommendations of the Board.

George W. Housner was appointed by the Governor as Chairman of the Board, Joseph Penzien served as Vice Chairman, and its members were Mihran S. Agbabian, Christopher Arnold, Lemoine V. Dickerson, Jr., Eric Elsesser, I. M. Idriss, Paul C.Jennings, Walter Podolny, Jr., Alexander C. Scordelis, and Robert E. Wallace. John F. Hall served as Technical Secretary, and Ben Williams served as Administrative Officer in support of the Board; Charles C. Thiel Jr. served as the Technical Writer and Editor of the Board's Report.

The Board of Inquiry gathered its information through presentations from Caltrans and independent experts in seismology, structural engineering, geotechnical engineering, and other disciplines. Most of the information was presented at public hearings held in Sacramento, the Bay Area, and Southern California, at which times public testimony was also invited. Reports and written information were sent directly to Board members for their review. The Board of Inquiry held seven public meetings between November 1989 and March 1990. Three of these were two-day meetings. A total of 70 individuals provided testimony at those meetings. In addition to these seven public meetings, Board members toured the Cypress test structure and several of the damaged San Francisco structures. An Annotated Bibliography in the Report contains a comprehensive listing of the materials that were sent or made available to all of the Board members for their use.

The Board concluded that future earthquakes in California are inevitable. Earthquakes larger than Loma Prieta with more intense ground shaking will occur in urban areas and have severe consequences - too large to continue "business as usual." The vast majority of structures that will fail in future earthquakes exist now - bridges, buildings, industrial facilities, and utilities. The Board of Inquiry identified three essential challenges that must be addressed by the citizens of California, if they expect a future adequately safe from earthquakes:

- Ensure that earthquake risks posed by new construction are acceptable.

- Identify and correct unacceptable seismic safety conditions in existing structures.

- Develop and implement actions that foster the rapid, effective, and economic response to and recovery from damaging earthquakes

These challenges are addressed not only to the design and construction of bridges, whose failure prompted the Board's formation, but also to all the other constructed facilities upon which our modern economy and well-being depend.

The Loma Prieta earthquake should be considered a clear and powerful warning to the people of California. Although progress has been made during the past two decades in 
reducing earthquake risks, much more could have been done, and awaits doing. More aggressive efforts to mitigate the consequences of earthquakes are needed if their disastrous potential is to be minimized and one of the most fundamental of responsibilities of government is to be fulfilled - to provide for the public safety.

The State of California must not wait for the next great earthquake, and the likely tens of billions of dollars in damage and thousands of casualties, to accelerate hazard mitigation measures. California must recognize that it has an earthquake problem that can be mitigated. It is hoped that the Board's findings and recommendations will provide a positive impetus toward actions that will provide adequate earthquake safety.

\section{THE EARTHQUAKE}

The Loma Prieta earthquake of October 17, 1989 (5:04 P.M., Pacific Daylight Time) occurred near three, large modern cities-San Jose, San Francisco and Oakland. It was named after the highest topographic point adjacent to the fault zone. The epicenter was in a sparsely populated, mountainous area. The fault rupture penetrated upward to within about 4 miles of the ground surface, but did not break the ground surface. This Magnitude 7.1 earthquake was felt from Los Angeles north to the Oregon State line, and east to western Nevada. It was the largest to occur in the San Francisco Bay area since the great San Francisco earthquake of 1906. The supplement to the May, 1990 issue of Earthquake Spectra provides a review of the earthquake and its impacts, [4].

This was the nation's first prime-time earthquake. It occurred during the opening ceremonies of the third game of the Wold Series, about to be played between the Oakland Athletics and the San Francisco Giants at Candlestick Park. Media coverage was intense from the very start, with live television focusing on the fire in the Marina, on damage to bridges, and on search and rescue operations broadcast to the nation well before the local community knew what had happened. Notwithstanding the emphasis of the news coverage on impacts 60 miles from the epicenter, the earthquake had major impacts on the counties to the south, as well as on Oakland and San Francisco. Two of the most dramatic impacts of the earthquake were the failures of the Cypress Viaduct and the link span of the San Francisco-Oakland Bay Bridge, both about 60 miles from the epicenter.

Over 1,300 buildings were destroyed, and 20,000 buildings damaged. More than 3,500 business were damaged and about 400 destroyed. Thirteen state-owned and five locallyowned bridges were closed to traffic following the earthquake, a very small number considering that there are over 4,000 bridges in the area. Forty-one people died in the Cypress collapse, and one died on the Bay Bridge in a traffic accident moments after the earthquake. The cost of the earthquake to the transportation system was estimated at $\$ 1.8$ billion, of which damage to State-owned viaducts totaled about $\$ 200$ million and damage to other State-owned bridges was about $\$ 100$ million. Fairly or not, the lasting legacy of the Loma Prieta earthquake probably will be the damage sustained by highway bridges.

The impacts of the earthquake were much more than the loss of life and direct damage. The Bay Bridge is the principal transportation link between San Francisco and the East Bay. It was out of service for a month and caused substantial hardship as individuals and businesses accommodated themselves to its loss.

The Loma Prieta earthquake was not unexpected. It occurred near an area of the San Andreas fault previously recognized as having a high potential for an earthquake of Magnitude 6.5 to 7.0 , having been assigned a $30 \%$ probability of occurrence in the 30 -year period beginning in 1988 [5]. Other major earthquakes of equal or greater Magnitude are also 
anticipated on the Hayward fault and other segments of the San Andreas fault, much closer to population concentrations than Loma Prieta.

The region affected by the strong, potentially damaging, ground motion extended from the Monterey Bay to the San Francisco-Oakland area (Figure 1) This area contains a wide range of modern engineered structures representing most forms of current construction: buildings, bridges, dams, tunnels, harbor works, pipelines, and manufacturing facilities. Shaking intensity was VIII on the Modified Mercalli Intensity scale (MMI) over an area of 30 miles long and 15 miles wide extending from Los Gatos to Watsonville and Santa Cruz. An outer zone of intensity VII extended 60+ miles northwest to San Francisco and Oakland, and 30 miles southeast to Salinas and Hollister. Within these regions, free-field, peak horizontal accelerations exceeded $60 \% \mathrm{~g}$ close to the source and were as high as $26 \% \mathrm{~g}$ at a distance of 60 miles. Strong shaking lasted less than 10 seconds.

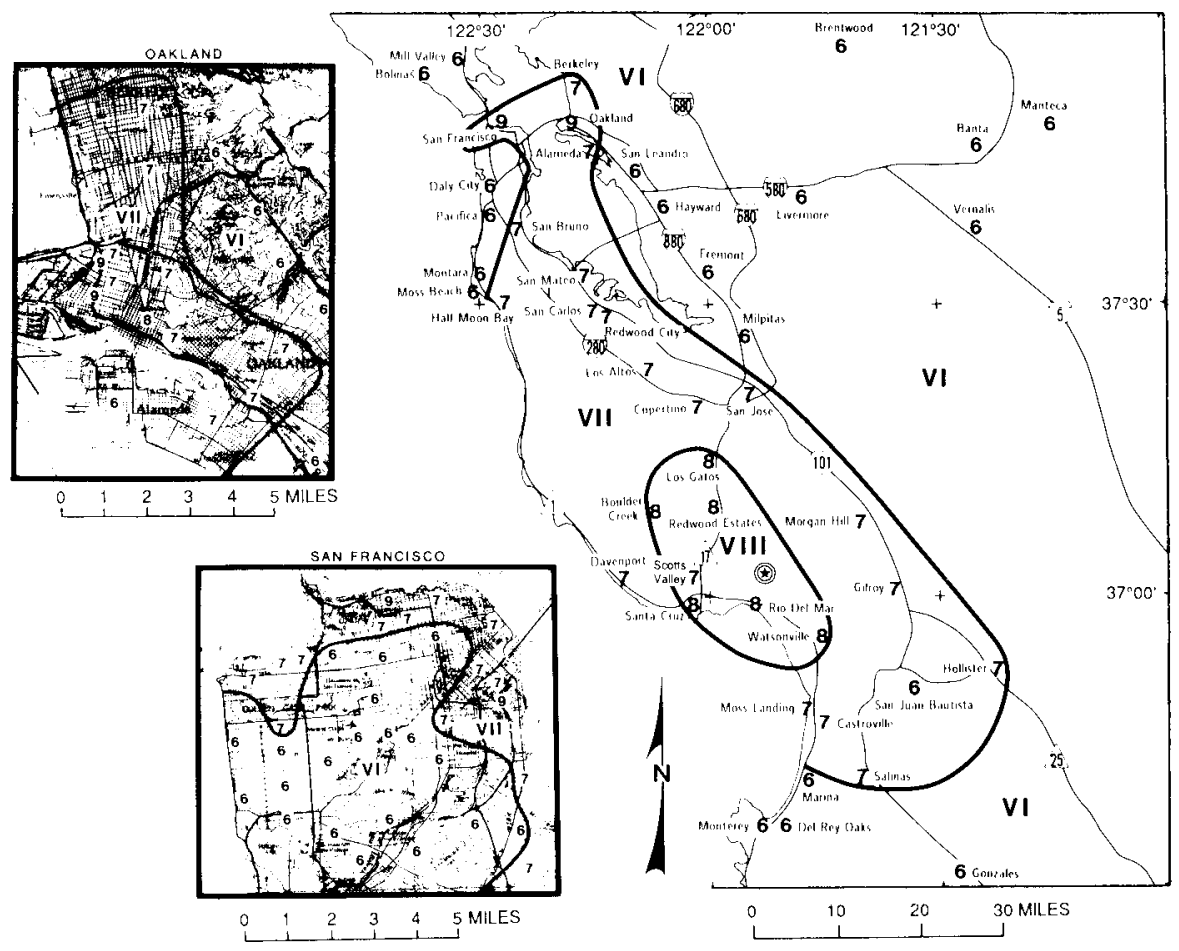

Figure 1. Isoseismal map of the damage impacts of the Loma Prieta earthquake. MMI VII is termed strong and is described by the types of effects observed: weak unreinforced buildings damaged; unreinforced masonry chimneys broken at roof lines; disruption of building contents; plaster cracked. MMI VIII is termed very strong shaking: damage to nonearthquake-resistant structures can be significant, with some collapses, particularly those in poor condition; damage to nonstructural elements in modern, seismically resistant buildings; and substantial disruption of building contents and toppling of unanchored equipment.

The regional damage distribution was unusual in several respects from what might have been expected. The duration of strong shaking was about half as long as typical for a Magnitude 7.1 earthquake; ground motions were lower than would have been expected in San 
Jose, near the source, and higher than expected in the San Francisco-Oakland area, distant from the source. The nature of the soil conditions, both in the epicentral region and in the Bay area, played a very strong role in the damage distribution in this as well as in most California earthquakes. The ground motions in the Bay Area at soft soil sites, where much of the damage to bridges and viaducts occurred, were significantly greater than the motions recorded at nearby rock and stiff soil sites. A soft soil site, as used in the balance of this Report, is defined as a site underlain by several feet to several tens of feet of young bay mud.

Many reports have been written that characterize the overall impacts of this earthquake on buildings and lifelines, see particularly the recent special issue of Earthquake Spectra on the Earthquake, [4]. Newer buildings generally performed well during and after the earthquake. Unreinforced masonry buildings experienced collapse and severe damage in the epicentral region and in the regions with poor soils, and these resulted in loss of life. Older wood frame houses in the Santa Cruz and Watsonville areas suffered severe damage from collapse of unbraced cripple walls and thousands were made homeless by such failures. Older wood frame residential structures in the Marina area of San Francisco sustained major damage due to weak first stories, principally because of garage openings, poor condition, and poor soils. Such observations have been repeated in California earthquake after earthquake.

The Loma Prieta earthquake caused disruption of utility services throughout the region. Water and sewage systems were severely damaged from the epicentral region to the San Francisco Bay area. Although electric power facilities and transmission routes in the earthquake-affected region suffered very little or no damage, initial power outages affected about 1.4 million users. Within 48 hours, service to most customers was restored. There was no reported damage to the major natural gas transmission and large distribution lines. Isolated failures in the local distribution system occurred in the East Bay and in the epicentral regions. The telephone system fared well during the Loma Prieta earthquake, except for one major switching facility that suffered substantial damage. The loss of commercial power caused some temporary communication problems.

One of the major characteristics of the Loma Prieta earthquake was its effect on transportation systems, mainly from damage to bridges and viaducts. Of the three major commercial airports-San Francisco, Oakland, and San Jose-in the affected area, only San Francisco International Airport closed for a period of time (about 12 hours) following the earthquake. At San Francisco Airport the control tower suffered minor damage; the runways suffered no damage, an air cargo building suffered major damage; and some passenger terminals suffered considerable nonstructural damage, including potentially serious fire-water sprinkler failures. At Oakland Airport the northern most 3,000 feet of the 10,000-foot main runway suffered extensive damage and was closed. The control tower at San Jose International Airport had minor nonstructural damage.

\section{OVERVIEW OF DAMAGE TO BRIDGES}

Only a small percentage of the bridges in the area sustained any earthquake damage at all. Moreover, according to testimony received by the Board, most of the bridges damaged in this earthquake were constructed prior to 1971 , before construction standards were stiffened to reflect lessons learned in the 1971 San Fernando earthquake. The greatest damage during the Loma Prieta earthquake occurred to older structures on soft ground.

State-wide, Caltrans currently maintains 11,287 highway and pedestrian bridges with spans over 20 feet, a number almost identical to the 11,229 bridges maintained for California local governments in the State. District 4, whose jurisdiction approximates the area of greatest earthquake damage, is responsible for 1,896 State bridges, of which 91 (4.8 percent) incurred some degree of damage (mostly minor) during the earthquake. Structural damage or the 
potential threat to public safety was sufficiently serious in the case of 13 State bridges that they were closed to traffic for some period of time. Table 2 lists the Caltrans bridges which sustained major damage.

Table 2. Caltrans bridges sustaining damage greater than $\$ 100,000$ during the Loma Prieta earthquake. Conditions are as of May 1, 1990.

\section{Name of Bridge Location Description of Damage}

\section{Bridges Closed to Public Traffic after the Earthquake:}

San Francisco-Oakland San Francisco Bay Bay Bridge (1-80) (Alameda Co.)

Upper and lower closure spans at Pier E9 fell; spans at Pier E23 were near failure; concrete pedestal base of Pier E17 cracked; connection bolts at Piers E-17 through E-23 damaged; opened for traffic after one month; 1 death and 12 injuries.

Cypress Street Viaduct Oakland (Alameda Co.) (1-880)

Collapse of 48 bents, causing the upper roadway to collapse onto the lower roadway; 41 deaths and 108 injuries with 1 subsequent death; demolished, reconstruction uncertain.

Struve Slough Bridge (SR 1)

West Grand Avenue

Viaduct (I-80)

Southbound connector over-crossing ( $1-980)$

Mora Drive over-crossing (I-280)

Central Freeway Viaduct (US 101)

Southern Freeway

Viaduct $(1-280)$

China Basin Viaduct (I-280)

Terminal Separation Viaduct (1-480)

Embarcadero Viaduct $(1-480)$

Route 92/101 interchange (US 101)

San Mateo-Hayward Bridge (SR 92)

Temescal Creek (I-80)

Distribution structure (1-580)

Distribution structure (1-580)

Fifth Avenue overcrossing (1-880)

Route 242/680 separation (SR 242)

West connector overcrossing (SR 242)

Benicia-Martinez Bridge (1-680)

Richardson Bay Bridge (US 101)

Pajaro River Bridge (US 101)

Alemany Viaduct (I-280)

Napa River Bridge (SR 37)

\section{Santa Cruz County}

Port of Oakland

(Alameda Co.)

West Oakland (Alameda Co.)

Santa Clara County

San Francisco

San Francisco

San Francisco

San Francisco

San Francisco

San Mateo County

Between San Mateo and Alameda Counties

Alameda County

Alameda County

Alameda County

Alameda County

Contra Costa County

Contra Costa County

Contra Costa County

Marin County

Santa Clara County

San Francisco

Solano County
Extensive collapse of the "twin" bridges; opened on January 25, 1990 after reconstruction.

Damage to bents, columns and earthquake restrainers; open to traffic after several days.

Damage to two outrigger bents; opened on October 23, 1989 .

Damaged column requiring reconstruction; opened to traffic after a fow hours.

Damage to bents and columns; retrofit required; portions are still closed.

Damage to bents; retrofit required; still closed to traffic.

Damage to bents; retrofit required; opened to traffic atter 6 weeks.

Damage to steel span bearings; retrofit required; still partially closed to traffic.

Damage to bents and columns; retrofit required; still closed to traffic.

Damage to bearings, expansion joints, footings, and columns; opened to traffic after 2 weeks.

Failure of steel rocker bearings; opened to traffic after a few hours.

after the Earthquake:

Several large cracks in concrete box culvert walls and ceiling.

Damage to bent caps and columns.

Damage to bent caps and columns.

Damage to columns, bent caps, bearings, and substructure.

Damage to bearing system at Bent 4.

Cracks and spalis; damage to bearings and joint seals.

Damage to open deck expansion joints.

Damage to bearings, caps, columns, and earthquake restrainers.

Anchor bolt and expansion joint damage; cracks and spalls.

Spalling and column damage; retrofit required.

Superstructure shifted 4" longitudinally; earthquake restrainers damaged. 
The most tragic impact of the earthquake was the life loss caused by the collapse of the Cypress Viaduct, while the most disruption was caused by the closure of the Bay Bridge for a month while it was repaired, leading to costly commute alternatives and probable economic losses. In addition, some of the steel rocker bearings supporting the Navigator Spans of the San Mateo-Hayward Bridge failed. This could have led to catastrophic damage if shaking had been longer or more intense.

On the other hand, the Board received reports of only very minor damage to the Golden Gate Bridge, which is founded on rock, and the BART Trans-bay Tube, which was specially engineered in the late 1960s to withstand earthquakes. A post-quake inspection of the Dumbarton Bridge, built during the 1980s with earthquake design criteria in mind, revealed no structural damage.

Bridges maintained by local governments also incurred damage, though none as catastrophic as some of the Caltrans structures. A partial survey by Board of Inquiry staff found that at least 43 locally maintained structures in the earthquake area were damaged, of which at least 5 were closed to traffic for some period of time, but none collapsed. Reports from post-earthquake reconnaissance teams indicated that most local bridges performed remarkably well.

\section{Damage to the Bay Bridge}

Design of the San Francisco-Oakland Bay Bridge was completed in 1933 and construction was finished in 1936. It consists of two sections-a West Bay Crossing from San Francisco to Yerba Buena Island and an East Bay Crossing from Yerba Buena Island to Oakland (Figures 2 and 3 ). The total distance along the alignment from the San Francisco anchor of the West Bay Crossing to Pier E39 of the East Bay Crossing is 4.35 miles. The bridge is of double-deck design, with the upper deck carrying five lanes of traffic in the westerly direction and the lower deck carrying five lanes of traffic in the easterly direction. The lower deck had been originally designed for trains.

The West Bay Crossing consists of a twin suspension structure. Its total length is 1.95 miles. Both anchorages and the main supporting piers are founded on rock. The East Bay Crossing consists of four shallow simple-span trusses on Yerba Buena Island, a long cantilever truss structure, five deep simple-span trusses, fourteen shallow simple-span trusses, and a number of simple-span deck systems that use steel and concrete stringers supported on transverse concrete bents. The total length of the East Bay Crossing is 2.14 miles.

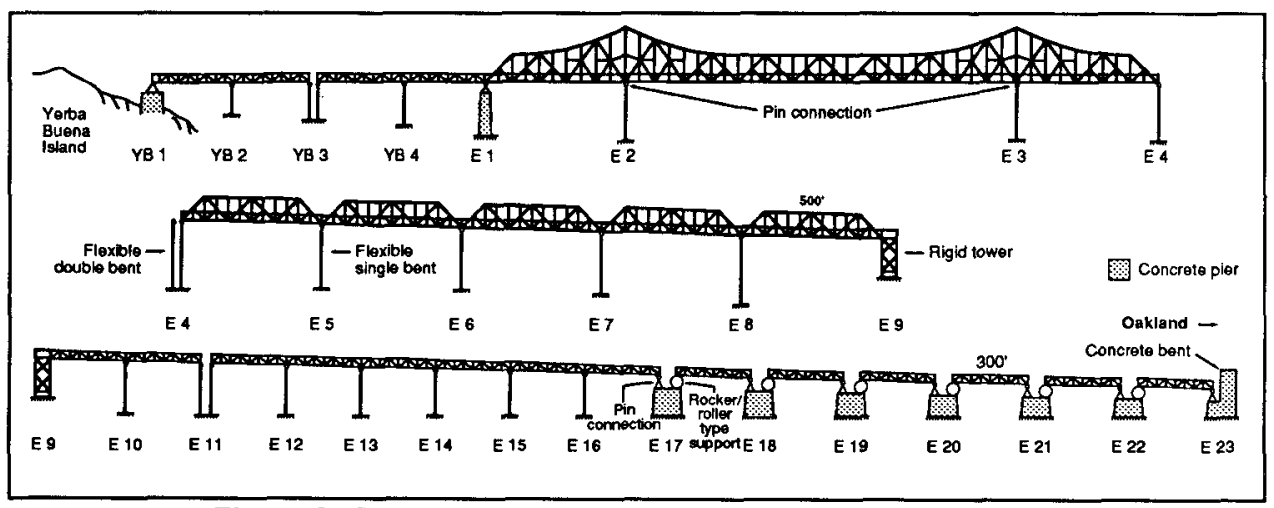

Figure 2. The east sections of the San Francisco-Oakland Bay Bridge showing support conditions 


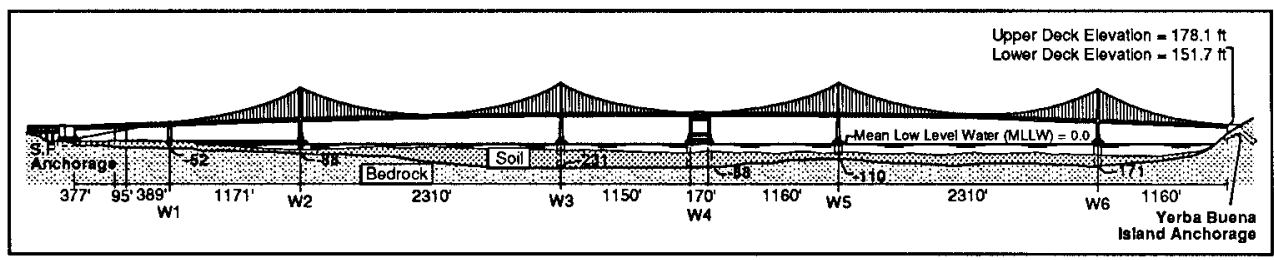

Figure 3. The west sections of the San Francisco-Oakland Bay Bridge

The Bay Bridge was designed for $10 \%$ g earthquake accelerations, comparable to the levels specified in the 1930 Uniform Building Code for buildings. It should be noted that knowledge of damaging earthquake motions was very limited at this time; the first few measurements of strong ground motions were not made until the 1933 Long Beach earthquake. There had been some seismic strengthening of the Bay Bridge with the installation of cable restrainers in the $1970 \mathrm{~s}$

The principal earthquake damage to the bridge was the failure of the upper and lower closure spans at Pier E9. It was closed for one month for repair. These 50 foot long upper and lower closure spans fell when the bolts failed that connected the pier and the 290' truss to the east (Figure 4). Another span at Pier E23, close to the eastern edge of the bridge, was near failure of a comparable type. Connections at Piers E18-E23 also failed. The concrete pedestal bases of Pier E17 cracked when the pier rocked back and forth and incurred some damage at the corners.

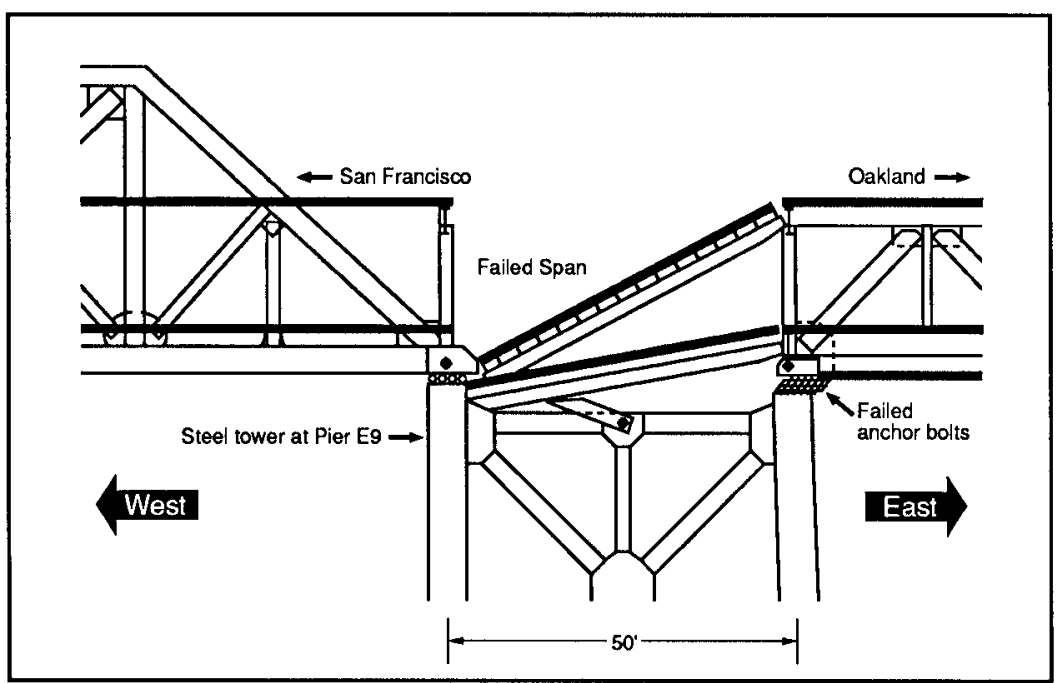

Figure 4. The upper and lower closure spans fell when the bolts attaching the east (right) truss-span were severed and it moved to the east, pulling the link spans off their western supports.

The closure spans linking the two long-span trusses on each side of pier E9 were supported on five inches of bearing on six-inch wide seat-type expansion joints at the west end and bolted connections at the east end. When the truss to the east broke free from its support, the closure spans were pulled with it, and the motions were large enough to slide them off the five-inch seats. As a result, the spans hinged down under gravity load, with the upper span 
coming down on the lower one. These hit an electrical housing before coming to rest on the west truss connection to the pier.

The approximate five-inch permanent displacement of the eastern span relative to Pier E9 was removed by jacking the trusses back into place. High strength bolts were used to attach the trusses to the pier, and larger seats for the replacement closure spans were installed. The trusses at Piers E18 through E22 were also jacked back into position and connected to the piers with high strength bolts. Replacement restrainers were installed at these locations. The seismic adequacy of these repairs, and of the bridge itself, in the event of a severe earthquake needs to be investigated and any necessary long-term seismic upgrading completed expeditiously.

The level of ground shaking in the Loma Prieta earthquake was smaller in both duration and intensity than that expected in larger and closer earthquakes. Moreover, the duration was not sufficient to excite all the different modes of the Bay Bridge's response that are likely in a longer duration event, nor was the level of shaking sufficiently close to that expected in major earthquakes to test the strength of bridge elements.

\section{The Cypress Viaduct Collapse}

The Cypress Viaduct was California's first continuous double-deck freeway structure, a design used again for the San Francisco Freeway Viaducts, but nowhere else in the State. Each deck of the Viaduct carried 4 lanes of traffic. During the Magnitude 7.1 Loma Prieta earthquake, a large portion of the Cypress Viaduct collapsed (Figure 5). This collapse was the most tragic consequence of the Loma Prieta earthquake. Forty-one people died. Search and rescue operations continued for a week. Fortunately, traffic conditions were very light compared to normal for the middle of rush hour, due to the start of the televised third game of the World Series at Candlestick Park. Caltrans demolished and removed the standing portions of the structure and resurfaced the frontage roads by January.

Caltrans began preliminary design of the Cypress Viaduct in 1949 and construction was undertaken between 1954 and 1957, during a period when little was known about seismic design of reinforced concrete structures. It was one of the earliest uses of prestressed concrete in U.S. bridges. More significantly, the Cypress Viaduct was designed before research had developed procedures for achieving ductility in over-stressed structural members, and, therefore, the columns and joints failed in a brittle manner when overloaded. The Caltrans seismic design criteria in effect during 1949 to 1954 were introduced in 1943 and stipulated only a seismic strength coefficient of $0.06 \mathrm{~g}$.

The Cypress Viaduct was a reinforced concrete structure with some prestressing and two levels of elevated roadway. The box girder roadway was supported by a series of 83 twostory bents. Forty-eight bents collapsed in the October 17th earthquake, numbers 63 through 112 with the exception of Bents 96 and 97 that remained standing (the middle portion of Figure 5). A number of the bents had post-tensioned concrete transverse girders at the top level. The Cypress design did not incorporate ductility, since this was not common until the 1970s. Longitudinal cable restrainers were installed in 1977 at all transverse joints in the box girder bridge superstructure to provide continuity. The northerly two-thirds of the Cypress Viaduct, the major portion that collapsed, was founded on about 7 ' of dense-to-stiff artificial fill overlying a pre-existing triangular-shaped tidal marsh composed of soft bay mud and old slough channels that parallel the west side of the viaduct structure. 


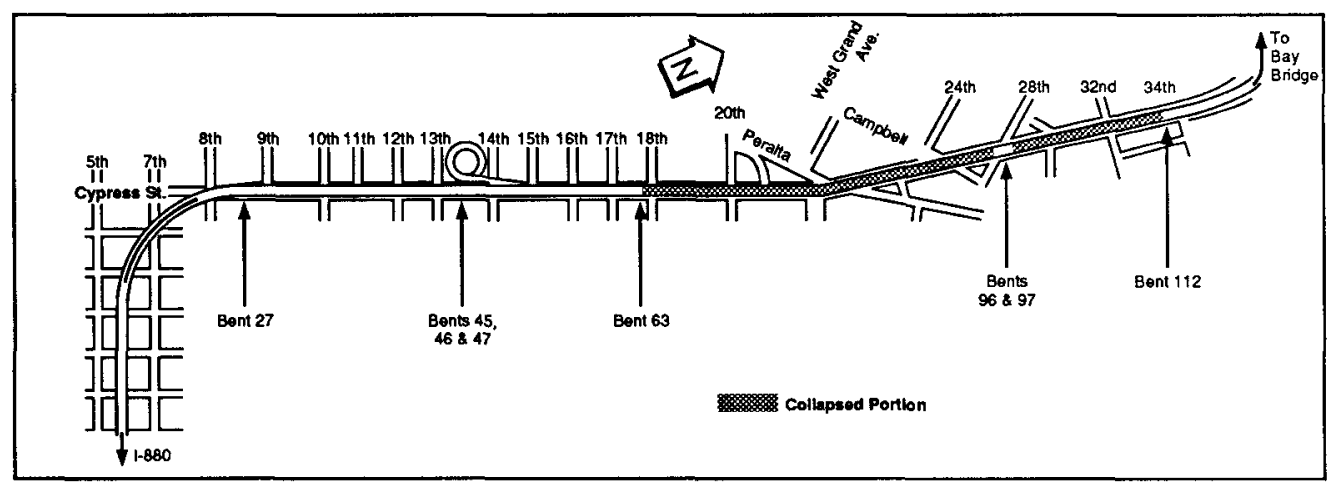

Figure 5. The Cypress Viaduct showing the extent of the collapse.

Failure occurred in the lower girder-to-column joints on both sides of a bent, with initial failure in the short column stub above the top of the lower deck and below the shear key. The failure surface was defined by the plane of the curved negative moment reinforcement bent down into the joint. The shear key did not fail in pure shear, as evidenced by the cone of concrete still attached to the four \#10 bars that extended through the key into the lower column. The upper girder-to-column joint sometimes failed completely, but in other cases was just severely cracked. Almost all the damage in this upper joint seems to have been produced as a result of the collapse of the upper deck onto the lower deck. The \#4 transverse ties in the joint region, as well as those in the column region, either failed or were severely damaged.

Examples of this type of bent failure are Bents 63-69, Bents 81-94, and Bents 99-103.

The common failure mode is illustrated by the sequence shown in Figure 6. A diagonal crack formed in the stub and lower girder-to-column joint regions. This crack followed a plane of weakness in the joint region defined by the plane of the bent-down negative moment girder reinforcement. Then the gravity and seismic forces pushed the upper column down and away from the joint, resulting in the collapse of the upper deck. Much of the damage to the upper columns, roadway, and girders was subsequently caused by the impact of the upper deck on the lower deck. Experiments performed on standing portions of the Cypress as well as static and dynamic analyses indicate that the calculated seismic demands during the Loma Prieta earthquake required to initiate failure in this nonductile structure were greater than the available structural capacities.

\section{San Francisco Freeway Viaducts}

The Loma Prieta earthquake was, for the San Francisco Freeway Viaducts, a minor-tomoderate earthquake. These viaducts (Embarcadero Freeway, Terminal Separation Viaduct, Central Viaduct, China Basin Viaduct, Southern Freeway Viaduct and Alemany Viaduct) in San Francisco (Figure 7) were all built with the same technology used for the Cypress Viaduct and are the only structures in the State of this design. All of the freeway structures, with the exception of the Alemany Viaduct, were damaged during the earthquake and subsequently closed to traffic.

The San Francisco Freeway Viaducts are composed of single-column and multi-column bents, typically with two tiers, but with a maximum of three tiers, of framing supporting two levels of roadway. The transverse lateral load resisting system in the multi-column bents 
typically consist of pinned-base single-story portal frames with one or more columns cantilevering to the upper level bent cap (girder). The reinforcement in the columns and girders was generally poorly detailed by current standards and reflects the engineering profession's lack of understanding regarding the inelastic response of reinforced concrete members at the time when these structures were designed. In the longitudinal direction, none of the six freeway structures have a planar lateral load resisting system. A lack of redundancy and the inadequate reinforcement detailing are two of the major seismic deficiencies in these freeway structures.

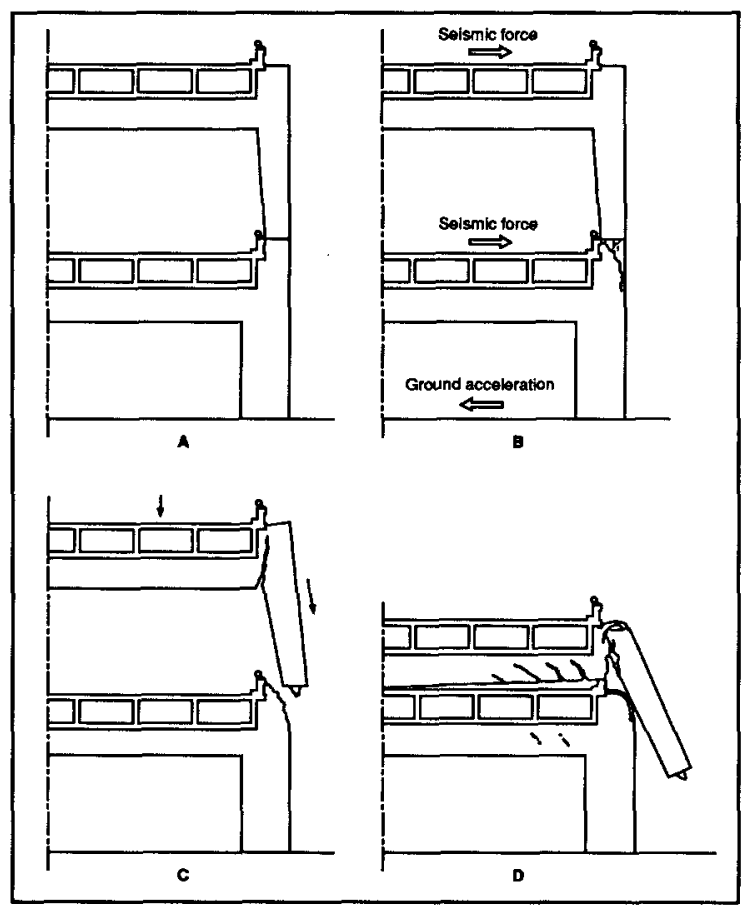

Flgure 6. Typical failure sequence of the prevalent style bent (B1). All but seven of the 48 collapsed bents failed in this way. For further discussion see the Report and Nims et al, [10].

Damage to the individual viaducts varied and included shear cracking in columns, girders, and joints; torsional cracking in outrigger bents; anchorage failure of the girder reinforcement; and shear key failure, among others. Many of the crack patterns are similar to those observed in the collapsed and damaged portions of the Cypress Viaduct.

After the 1989 earthquake, Caltrans retained six consultants to prepare contract documents for the upgrading of the six designated freeway structures. The criteria set by Caltrans for the development of the upgrading schemes were outlined in a series of letters and memoranda and included requirements for the analysis of the freeway structures and interpretation thereof, and design and detailing requirements. The damage criteria set by Caltrans accepts serious damage, but not collapse, during severe earthquake shaking. These designs were latter reviewed by a Caltrans appointed independent review panel, at the suggestion of the Board, and at this writing under substantial discussion. 


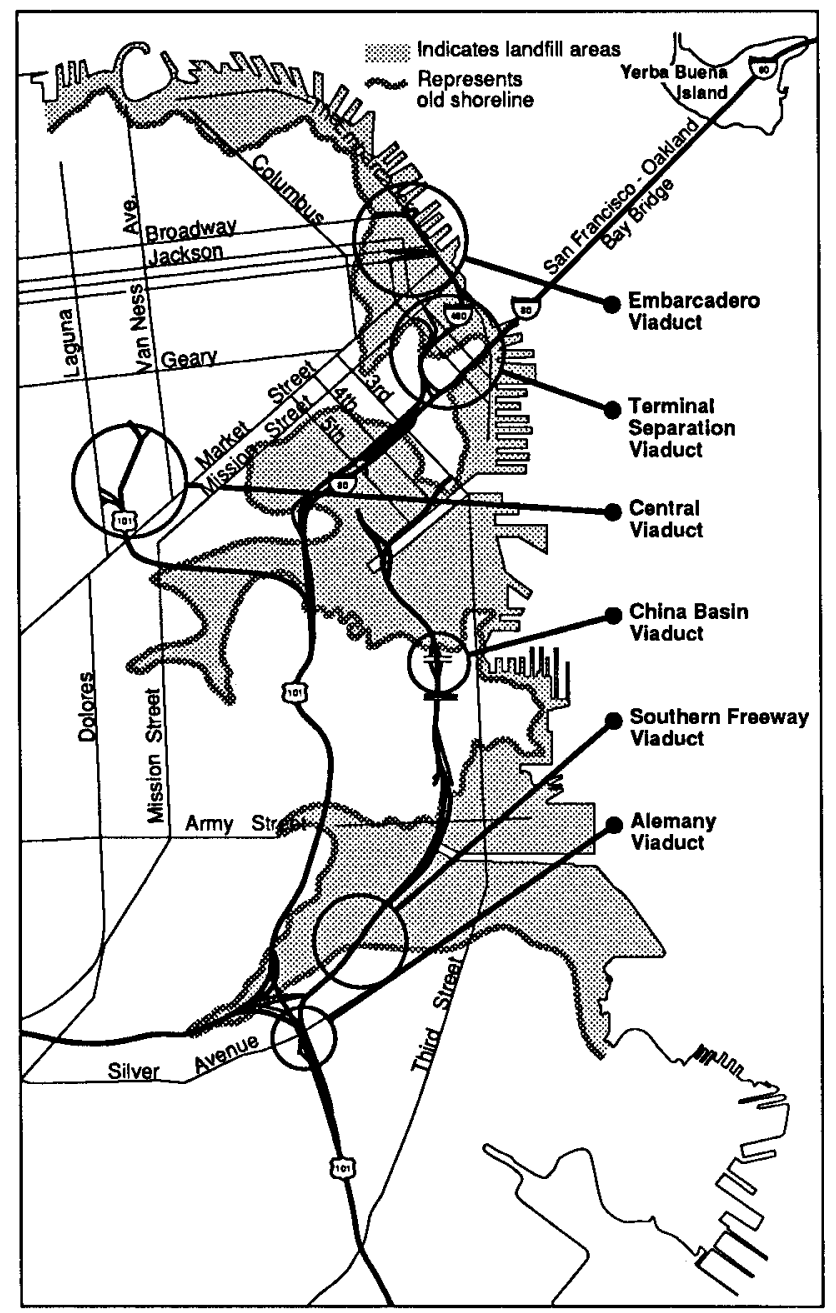

Figure 7. Location of the damaged San Francisco Freeway Viaducts .

\section{Collapse of the Struve Slough Bridge}

The Struve Slough Bridge is located on California Highway 1 between Watsonville and Santa Cruz and consists of side-by-side structures constructed in 1964. One structure carried northbound and the other southbound traffic. These structures are about $800^{\prime}$ long and $34^{\prime}$ in width with spans of 37'. Typical of structures built at this time, they were of a reinforced concrete T-beam construction supported on pile bents. There were three deck expansion joints in the length of each structure, effectively dividing the length of each structure into four segments. Seismic retrofitting, completed in 1984, consisted of the addition of cable restrainers at each expansion joint. 
These structures were supported along their length by 22 pile bents and on monolithic diaphragm abutments at the ends. Each bent consisted of four driven piles, which were approximately $80^{\prime}$ long and driven to full length. Each pile was then extended by reinforced concrete columns to the underside of the superstructure into transverse cap beams. The pile extensions were lightly confined with number 3 wire at about 12 " pitch.

As a result of the earthquake, these structures experienced extremely strong shaking which led to the collapse of the center two segments of each structure. Pile extension columns within these center two segments suffered severe cracking, buckling of longitudinal reinforcing, and fracture of the lateral confining reinforcement. Most of the columns sheared off at the interface with the underside of the transverse cap beams. Seven spans of the northbound structure collapsed, dropping approximately $5^{\prime}$ onto the damaged pile extension columns. Ten spans of the southbound structure collapsed, dropping approximately $8^{\prime}$ to $10^{\prime}$ to the ground surface. A few pile extension columns, sheared at the transverse cap beams, displaced and punched through the deck slab as the structure fell to the ground. Although the collapse was generally in the downward direction, the southbound structure displaced transversely approximately 2 '.Some piles also apparently failed below the ground surface. Soil displacements at the ground surface around the piles in several directions were up to a maximum of 18 " at several piles. The approach fills settled approximately $3 "$ ".

The structure showed little evidence of significant seismic forces reaching the superstructure above the abutments. There was no indication of horizontal movement at the abutments or hammering at the expansion joints. Despite the displacements experienced by the collapsed structures, the cable restrainers performed well and held the structure together.

The primary cause of collapse is attributed to a lack of adequate concrete confinement and shear reinforcing at the top of the columns. Current practice and standards would require ductile detailing of these members, which would have led to substantially better seismic performance.

\section{IMPACTS ON CROSS-BAY TRANSPORTATION}

San Francisco Bay stretches some 65 miles from Alviso in the south to its northern boundary at the Richmond-San Rafael bridge in the north. Beyond this bridge the stretch of water becomes San Pablo Bay, which ends at the Carquinez Bridge near Vallejo. Besides the Richmond-San Rafael Bridge, San Francisco Bay is crossed by three other bridges: the San Francisco-Oakland Bay Bridge, the San Mateo Bridge, and the Dumbarton Bridge. The Bay exits to the Pacific Ocean under a fifth bridge-the Golden Gate. In addition the bay is traversed by the Bay Area Rapid Transit (BART) Trans-bay Tube between Oakland and San Francisco (Figure 8). The Carquinez, Antioch, and Benicia-Martinez Bridges cross the San Pablo Bay .

The importance of integrating the Bay Area by bridging the water barrier between San Francisco and its neighbors was recognized early in the century. In 1912 the engineer John Freeman predicted that the population of the five Bay counties would reach 2 million within forty years, and that towards the end of the century a population of 3 million might be reached depending upon "the wisdom and vigor with which San Franciscans seize their opportunity" [6]. He was very close to correct in his first estimate, but by 1980 the five bordering San Francisco Bay counties had a population of 4.29 million, which is projected to rise to 5.24 million by the year 2005 [7]. 


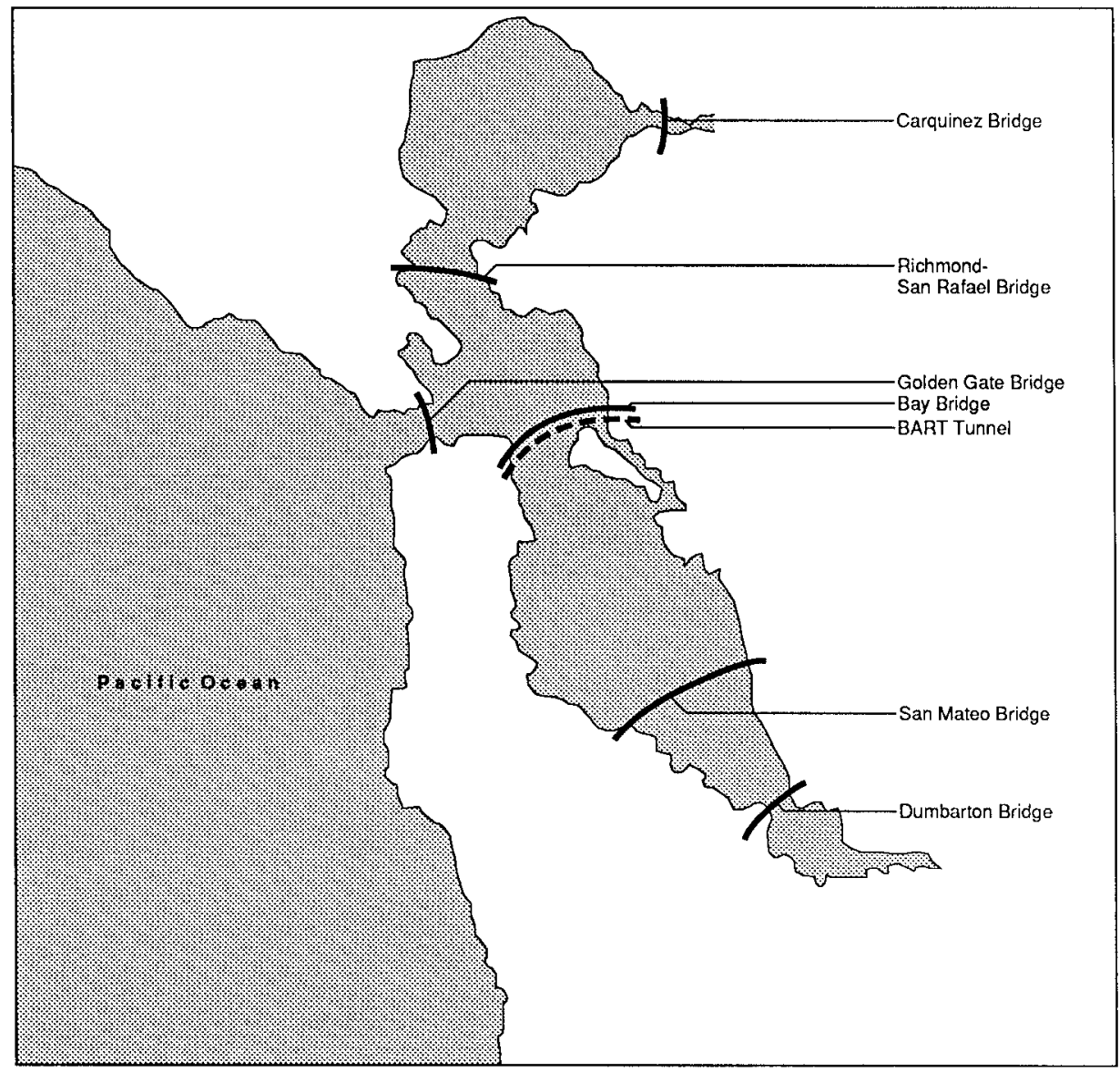

Figure 8. Principal transportation links across the San Francisco and San Pablo Bays.

The San Francisco Bay crossings form a crucial part of the entire Bay Area transportation network. In the 9 Bay Area counties, about $20 \%$ of workers are employed outside their county of residence. By the year 2005 it is estimated that this percentage will grow to slightly under $25 \%$. At the same time, automobile ownership in the area is expected to rise from today's 3.3 million autos to 5.1 million in the year 2005 [7]. Hence the Bay Area highway network will continue to be crucial to the economy, but its maintenance as a swift and convenient means of travel will become increasingly difficult.

Before the Loma Prieta earthquake, the total number of vehicles on the five San Francisco Bay bridges was an average of 517,000 per weekday, together with an average of 108,000 passengers on the BART Trans-bay Tube and the ferries. The breakdown of this traffic is given in Table 3. Two facts stand out: the importance of the Oakland-San Francisco link, and the volume of traffic borne by the San Francisco-Oakland Bay Bridgeapproximately double that of the Golden Gate Bridge, and almost equal to the combined traffic carried by all four other bridges. For automobile traffic, the Golden Gate and Bay bric ${ }^{3}$ res are essentially nonredundant systems, with alternative routes via the other bridges being time consuming to a level that seriously impacts commercial and institutional productivity. In contrast to freeways, which are superimposed over an existing (if inadequate) road pattern that 
is still available if a section of freeway is knocked out, the cross-bay bridges have no satisfactory alternative.

Table 3. Traffic use of the San Francisco Bay transportation links before and after the Loma Prieta earthquake.

\section{Total Vehicles, two-way, weekdays:}

San Rafael Bridge
Golden Gate Bridge
Oakland-Bay Bridge
San Mateo Bridge
Dumbarton Bridge

BART tube

All ferries

\section{Before Earthquake}

$$
\begin{array}{r}
44,000 \\
123,754 \\
243,116 \\
65,000 \\
41,500 \\
\\
102,152 \\
6,250
\end{array}
$$

\section{After Earthquake}

$$
\begin{array}{r}
79,173 \\
150,927 \\
0 \\
109,791 \\
67,189 \\
\\
226,876 \\
21,057
\end{array}
$$

\section{Difference}

$$
\begin{array}{r}
+79.9 \% \\
+21.9 \% \\
-100.0 \% \\
+68.9 \% \\
+61.9 \% \\
+122.1 \% \\
+236.9 \%
\end{array}
$$

When the Loma Prieta earthquake damaged the Bay Bridge, causing immediate closure of the most widely used cross-bay route for an indeterminate period, Bay Area traffic patterns were forced to change, and rapid planning had to be done to accommodate the situation. During the period of closure of the Bay Bridge, traffic was redistributed, as detailed in Table 3. Part of the apparent change in cross-bay totals owes to the fact that BART and the ferries count individual fares while the bridges count vehicles.

The critical role played by the BART Trans-bay Tube in cross-bay transportation is clear, as is the fact that the South Bay bridges (San Mateo and Dumbarton) accommodated most of the redistribution of vehicular traffic. While emergency ferry service more than tripled, from 6,250 to 21,057 passengers, the number of people carried was still well below that of automobiles and the BART system. Total vehicles over the crossings dropped from 517,370 to 407,140 during the closure period; a lot of people used BART or curtailed their travel. The effect of this pattern was noticeable in San Francisco-for example, restaurants in the city were virtually empty during this period, and suffered severe economic losses.

That the economic and personal losses of the Bay Bridge closure were considerable is not in doubt, although much detailed study would be necessary to define them fully. If the Bay Bridge had not opened within a month - a much shorter time interval than initially projected immediately after the collapse - the operational and economic consequences would have been much more severe. The equipment and maintenance facilities of BART, for example, were severely strained, and the post-earthquake increase in traffic could not have been sustained indefinitely. If the BART Trans-bay Tube or the Golden Gate Bridge had simultaneously been closed for a comparable time, the economic and social consequences could have been catastrophic.

This (fortunately) short closure of the Bay Bridge gave some indication of the disruption that could be caused by the loss of one of the essential cross-bay links. The Loma Prieta experience can be seen as a "live" exercise demonstrating the short-term closure of a single cross-bay link. A previous accident - the Trans-bay Tube fire in April, 1979-had resulted in a BART tube closure for two and one-half months. This experience also showed that failure of a single trans-bay crossing can be accommodated, albeit with some loss of convenience.

The consequences of earthquake damage to the Bay Area highway system (and a number of other urban "lifelines") were considered in two earthquake planning scenarios developed and published by the California Department of Mines and Geology for the Office of 
Emergency Services. The first, published in 1982, sketched the possible effects of a Magnitude 8.3 earthquake on the San Andreas Fault [8]. The second, published in 1987, considered the effects of a Magnitude 7.5 earthquake on the Hayward fault [9]. Both these studies were intended not as predictions but as carefully considered pictures of what might happen if the scenario earthquakes occurred, with the primary objective of making emergency response and recovery authorities aware of the types and degree of situations that they might have to face. While they were carefully prepared and appropriate for planning purposes, they were not the result of engineering analyses of the expected performance of the physical structures they considered.

The Loma Prieta earthquake showed the vulnerability of a Bay Crossing and other critical links in the freeway system to a relatively distant event. Future planning must recognize the likelihood and potential consequences of closer, and more powerful events on the San Andreas and Hayward faults. In particular, the possibility of a dual, or even triple failure, of Bay crossings would result in a situation for which there has been no precedent.

Moreover, even if additional retrofits are implemented for the Bay Bridge, and the Trans-bay Tube and the Golden Gate Bridge are deemed safe, the possibility of postearthquake closure is always present, because no engineering measures can guarantee a damage-free response.

The Bay crossings represent one component-perhaps that with the least redundancyof the entire Bay Area highway transportation system. This, in turn, forms part of a Statewide, indeed national, system-rail, air, ship-that is critical for the economic transportation of people, materials, and products. The transportation network itself forms one subsystem of the entire urban and regional structure of the State. In terms of future earthquakes it is necessary not only to identify and strengthen the weak links in bridges, but to protect the buildings and urban utility systems that enable our society to function.

The Loma Prieta earthquake gave other indications of earthquake effects on our physical, social, economic and political structures that must be attended to. While newer, well engineered, buildings fared well, much of our business, commercial and institutional activity still takes place in older buildings, constructed before seismic design and construction was well advanced. Only slowly, at the rate of about $2 \%$ a year, is our older building inventory being upgraded and/or replaced.

Many of the older governmental buildings in the area - often of great architectural merit, such as the San Francisco and Oakland City Halls-suffered considerable structural and nonstructural damage. Six months after the earthquake, Oakland City Hall is still unusable, and San Francisco is evaluating alternative schemes for extensive repairs to its administrative center and other important institutional buildings. The damage to these buildings, just below the threshold of life-threatening structural failures and collapses, must be understood as far less than that which would be incurred during future high probability earthquakes of the same or greater Magnitude on closer sections of the San Andreas or Hayward faults.

Only aggressive programs of identification and strengthening will prevent the possibility of perhaps scores of tragic collapses similar to that of the Cypress Viaduct in the event of a future closer earthquake of long duration. In addition, the economic and administrative effects would be deep and long-enduring, and might threaten the viability of California as an attractive environment in which to live and work. 


\section{FINDINGS AND RECOMMENDATIONS}

Central to the Board's process has been the determination of what occurred during the earthquake and why. These findings formed the basis for the recommendations made by the Board of Inquiry. A great deal of information was considered, some provided through public presentations to the Board, other through study of documents and files. The fifty-two findings of the Board were organized under the following general headings:

1. Findings on seismology and ground motion

2. General findings on transportation structures

3. Findings on Caltrans seismic design practices

4. Findings on the Bay Bridge failure

5. Findings on the Cypress Viaduct collapse

6. Findings on San Francisco Freeway Viaducts

7. Findings on the Caltrans retrofit program

8. Findings for other types of structures

The specific finding statements are reproduced in the Appendix. The full report presents a discussion that gives the rationale for each finding and the technical information on which they were based.

Based upon these findings the Board of Inquiry has identified three essential challenges that must be addressed by the citizens of California, if they expect a future adequately safe from earthquakes:

- Ensure that earthquake risks posed by new construction are acceptable.

- Identify and correct unacceptable seismic safety conditions in existing structures.

- Develop and implement actions that foster the rapid, effective, and economic response to and recovery from damaging earthquakes.

These challenges address not only the problems of bridges, whose failure prompted the Board's formation, but also all the other constructed facilities upon which our modern economy and well-being depend. The Board might have limited its recommended actions only to those it believes necessary to correct problems with State-owned bridges. But to do so would have been to abdicate consideration of the most fundamental of responsibilities of government-to provide for the public safety. The Board interpreted its Charter in a broader sense and made recommendations that are directed both at seismic issues for bridges and some of the larger issues of seismic safety facing the State.

The Board made eight Recommendations for implementation:

\section{For Action by the Governor:}

1. Affirm the policy that seismic safety shall be a paramount concern in the design and construction of transportation structures. Specific goals of this policy shall be that all transportation structures be seismically safe and that important transportation structures maintain their function after earthquakes.

2. Establish that earthquake safety is a priority for all public and private buildings and facilities within the State by taking the following actions:

A. Propose legislation to ensure that every new facility in the State not otherwise subject to adequate seismic regulation and having the potential to cause substantial 
life loss during an earthquake be subject to compliance with adequate seismic safety standards for construction.

B. Require that seismic safety be a paramount concern in the design and construction of all State-owned structures. Specific goals of this policy shall be that all Stateowned structures be seismically safe and that important State-owned structures maintain their function after earthquakes.

C. Initiate and fund a vigorous, comprehensive program of research to improve the capability in engineering and the physical and social sciences necessary to mitigate earthquake hazards and to implement the technology transfer and professional development necessary to hasten practical use of research results.

3. Direct the Seismic Safety Commission to review and advise the Governor and Legislature periodically on State agencies' actions in response to the Recommendations of this Board of Inquiry.

\section{For Action by the Director of the Department of Transportation:}

4. Prepare a plan, including schedule and resource requirements, to meet the transportation seismic performance policy and goals established by the Governor. The plan shall include the timely seismic retrofitting of existing transportation structures.

5. Form a permanent Earthquake Advisory Board of external experts to advise Caltrans on seismic safety policies, standards, and technical practices.

6. Ensure that Caltrans seismic design policies and construction practices meet the seismic safety policy and goals established by the Governor:

A. Review and revise standards, performance criteria, specifications, and practices to ensure that they meet the seismic safety goal established by the Governor and apply them to the design of new structures and rehabilitation of existing transportation structures. These standards, criteria, and specifications are to be updated and periodically revised with the assistance of external technical expertise.

B. Institute independent seismic safety reviews for important structures.

C. Conduct a vigorous program of professional development in earthquake engineering disciplines at all levels of the organization.

D. Fund a continuing program of basic and problem-focused research on earthquake engineering issues pertinent to Caltrans responsibilities.

7. Take the following actions for specific structures:

A. Continue to sponsor and utilize the Independent Review Committee's technical reviews of the engineering design and construction proposed for the short-term repair and strengthening of the San Francisco Freeway Viaducts.

B. Develop a long-term strategy and program for the seismic strengthening of existing substandard structures, including the San Francisco Freeway Viaducts, that considers their overall behavior, the degree of seismic risk, and the importance of the structure to the transportation system and community.

C. Perform comprehensive earthquake vulnerability analyses and evaluation of important transportation structures throughout the State, including bridges, viaducts, and interchanges, using state-of-the-art methods in earthquake engineering.

D. Implement a comprehensive program of seismic instrumentation to provide measurements of the excitation and response of transportation structures during earthquakes. 


\section{For Action by Transportation Agencies and Districts:}

8. Agencies and independent districts that are responsible for transportation systems-rail systems, highway structures, airports, ports and harbors - should:

A. Adopt the same seismic policy and goals established by the Governor for State transportation structures and implement seismic practices to meet them.

B. Perform comprehensive earthquake vulnerability analyses and evaluations of important transportation structures-e.g., the BART Trans-bay tube and Golden Gate Bridge-using state-of-the-art methods in earthquake engineering, and install seismic instrumentation

C. Institute independent seismic safety reviews for important structures.

D. Conduct a vigorous program of professional development in earthquake engineering disciplines at all levels of their organizations.

\section{GOVERNOR'S QUESTIONS}

The Governor directed the Board of Inquiry to address five specific issues arising from the Loma Prieta earthquake, [2]:

1. To determine why the Cypress Viaduct of Interstate 880 and the Bay Bridge span failed in the earthquake.

2. To determine whether these failures were or could have been foreseen.

3. To advise on how to accurately predict possible future bridge and structure failures.

4. To determine if the schedule for and manner of retrofitting these structures properly utilized the seismic and structural information that has been developed following other earthquakes in California.

5. To make recommendations as to whether the State should modify the existing construction or retrofit programs for freeway structures and bridges in light of new information gained from this earthquake.

To this group the Board has added the question:

6. Are California's freeways earthquake-safe?

Summary responses to the six specific issues, recast as questions, are given below. Background information and more detailed discussion of these responses are to be found in the Board's Report, [3].

\section{Why did the Cypress Viaduct of Interstate 880 and the Bay Bridge span fail in the earthquake?}

The Cypress Viaduct and Bay Bridge appear to have no design or construction deficiencies as measured by bridge design practices in effect at the time they were built, nor is there evidence of subsequent maintenance deficiencies that contributed to their failure. However, the practice of earthquake engineering has improved substantially from that of the periods during which the Cypress Viaduct (1950s) and San Francisco-Oakland Bay Bridge (1930s) were designed and constructed. 
The Cypress Viaduct was designed and constructed to Caltrans seismic practices for reinforced concrete when it was built in the 1950s. Caltrans and the American Association of State Highway and Transportation Officials (AASHTO) seismic design codes had very low seismic requirements at the time of design of the Cypress Viaduct compared to those for buildings as specified by the Uniform Building Code of the same period and compared to current standards. The Cypress Viaduct was a brittle structure, possessing very little ductility, which is consistent with the practices of the period. It is generally agreed that soft ground, such as that beneath the collapsed sections of the Cypress Viaduct, on the border of San Francisco Bay amplified ground motions in this earthquake more than anticipated by current codes. However, these ground motions were not as high at Cypress as those expected in likely, large earthquakes. The combination of nonductile reinforced concrete, inopportune placement of hinges in the upper story columns to accommodate future proposed widening and post-tensioning required in some girders, and weak second story column pedestals coupled with the large mass of the decks led to severe over stressing of the pedestals and columns supporting the upper deck, failure of the pedestals below the column shear keys, and the collapse of the structure.

The Bay Bridge was designed for $10 \% \mathrm{~g}$ static equivalent loadings, comparable to the levels specified for earthquakes in the 1930 Uniform Building Code for buildings. The 50foot-long upper and lower closure spans of the Bay Bridge over Pier E9 fell during the Loma Prieta earthquake. Ground shaking at the base of the bridge during the earthquake caused response motions of the bridge sufficiently large to shear the bolts that connected the pier and the 290' truss-span to the east. The 50' closure spans linking the two long truss-spans on the west and east sides of the pier were supported on six-inch-wide expansion-type bearing seats at the west end and bolted connections at the east end. When the truss-span to the east broke free from its supports, the closure spans were pulled with it, and the motions were large enough to slide them off their six-inch bearing seats. As a result, the spans hinged down under gravity, with the upper span coming down on the lower one. These then came to rest on an electrical housing before striking the west truss-span connections to the pier. Another closure span at pier E23, close to the eastern edge of the bridge, was near failure of a comparable type.

\section{Were these failures foreseen or could they have been foreseen?}

No evidence was presented to the Board suggesting that Caltrans was specifically aware of the earthquake hazards that caused the failures of the Cypress Viaduct or the San Francisco-Oakland Bay Bridge. While there had been some seismic strengthening of both structures by the installation of cable restrainers, there is no other evidence that Caltrans had identified either as especially earthquake vulnerable.

Preparedness Plans developed by the State Office of Emergency Services and Division of Mines and Geology for Hayward and San Andreas earthquakes included assumptions that major bridges would be out of service, but not because of failure or collapse of the bridges themselves. Rather they assumed damage to approaches. It should be emphasized that these plans were formulated as planning assumptions for preparedness and were not based on any engineering assessment of the expected performance of the bridges themselves.

The issue of whether these failures could have been foreseen in the Loma Prieta earthquake is a difficult one because of the uncertainties and lack of previous studies. The fiscal environment at Caltrans in the last two decades seems to have inhibited giving the necessary attention to seismic problems. Many items ranging from research on earthquake engineering to seismic retrofitting were placed in low priority because of the limited possibility of funding due to budget constraints. 
The Board of Inquiry concludes that an engineering seismic assessment of the Cypress Viaduct before the earthquake, performed after 1971 by a professional engineering organization in a manner consistent with the care and expertise usually exercised in evaluating such important structures, would have concluded that a collapse could be expected during a nearby major earthquake on the San Andreas or Hayward faults. Damage, but not extensive collapse, would have been expected for an earthquake with Loma Prieta's magnitude and location. Collapse would have been anticipated for the intensity of ground motion observed in the Loma Prieta earthquake; however, the extent of the collapse that actually occurred would probably not have been anticipated.

The Cypress Viaduct was a nonductile concrete structure. It has been common knowledge within the structural engineering community for the past ten years that nonductile reinforced concrete structures are particularly earthquake vulnerable. Most Caltrans concrete bridges constructed before 1971 have nonductile details. Caltrans instituted design changes in 1971 , following the San Fernando earthquake, that required new construction to utilize ductile details. However, for the Cypress Viaduct retrofit of 1977 a prior decision in the retrofit program dictated that the limited available funds should be used to install longitudinal restraints at the transverse expansion joints in the box girder spans. This was done to prevent failures of the type experienced in the 1971 San Fernando earthquake. Unfortunately, no detailed comprehensive analysis of the entire structure-soil system was made until the time of the failure of the Viaduct on October 17, 1989 to determine if other weaknesses existed. If such an analysis had been made the Board believes the failure would have been predicted.

The Board thinks that a comprehensive seismic analysis of the Bay Bridge conducted before the Loma Prieta earthquake performed after 1971 by a professional engineering organization in a manner consistent with the care and expertise usually exercised in evaluating such important structures, would have concluded that it had serious seismic deficiencies.

The Bay Bridge is a very large and complicated structure made of steel and concrete and has foundations extending to rock or stiff soils through very soft, water-saturated soils. The assessment of seismic performance and possible damage to such a complex structure requires an unusually thorough and detailed investigation. Had such a study been made it probably would have identified the possibility of collapse of the link span in addition to other hazards.

\section{How may possible future bridge and structure failures be accurately predicted?}

At present earthquakes cannot be scientifically predicted. Thus, predicting the possibility of failures is confined to determining whether the bridge or structure could fail under a given level of ground shaking. Predicting this failure potential requires: first, that the level of ground shaking be determined for the site; and second, that an engineering assessment of expected performance be made for this ground shaking. The ground shaking used for such a failure analysis should be the ground shaking expected for the site determined from a probabilistic risk assessment, with a sufficiently small probability of exceedance during the projected lifetime of the structure, consistent with its importance. Special seismic analyses must be made to determine a structure's potential for collapse under these motions.

Faced with an inventory of over 11,000 State-owned and a comparable number of locally-owned bridges, it is not expected all can or should be assessed with such rigor. Since design standards used by Caltrans after 1971 were better than those used before, it is reasonable to expect that the older ones pose a greater risk. Application of risk analysis procedures that consider the frequency of occurrence of different levels of ground motion and the characteristics of the structure (configuration, materials, foundations, soils, age and condition) could reduce this to a manageable list of potentially hazardous structures. Locations 
with a potential for ground failure, e.g. liquefaction and lateral spreading, deserve special attention. Engineering analyses would then determine the potential for failure and the engineering steps required to meet the performance goals recommended to the Governor by the Board for new and existing transportation structures.

The Recommendations of the Board, when fully implemented, are intended to give reasonable assurance that both existing and new bridges and transportation structures provide adequate seismic safety.

\section{Did the schedule for and manner of retrofitting these structures properly utilize the seismic and structural information that has been developed following other earthquakes in California?}

Several freeway bridges collapsed in the 1971 San Fernando earthquake when decks were pulled off of their supports at expansion joints. The decks fell, causing failure of the bridges. This happened even though no direct damage was necessarily done to the bridge elements themselves by the ground shaking. This type of hazard was the weak link on many bridges that existed in 1971. In response, Caltrans adopted a cable restrainer seismic retrofit program to tie decks together and to their abutments to prevent such failures. It took 17 years and expenditures of $\$ 54$ million to complete this program. The Board believes this program significantly increased the seismic resistance of many structures. The Board's only major criticism is that 17 years was too long for completion of such an important program.

The Cypress Viaduct and the San Francisco-Oakland Bay Bridge had been retrofitted with cable restrainers to limit the relative motion between adjacent decks at expansion joints. No special seismic analyses were made of these structures. Following the 1971 earthquake, seismic design procedures for new structures were modified to include ductile detailing of concrete, but no special efforts were made to retrofit existing nonductile concrete bridge elements.

The near collapse of the I-5/I-605 overpass in the 1987 Whittier Narrows earthquake emphasized the need for strengthening nonductile concrete bridge columns. An ongoing research project was accelerated and an inventory was made of high-hazard-potential single column bridges. The Cypress Viaduct, being a multiple column bridge, was not identified as a high priority structure for attention.

Early in the retrofit program, Caltrans considered the performance of individual elements (restraining motion at expansion joints). Caltrans did not consider the response of the whole structure or the soil-structure system. This focus on elements, in hindsight, may have inhibited the likelihood of identifying problems in overall seismic behavior such as those uncovered in the failure of the Cypress Viaduct and the Bay Bridge.

The repair of the Bay Bridge appears to be appropriate for the short-term. The fact that the Bay Bridge was only slightly damaged during the Loma Prieta earthquake and the repair completed does not mean that the bridge may now be presumed to be adequately earthquake resistant. The expected performance of the bridge during major earthquake loadings should be assessed by comprehensive state-of-the-art methods in earthquake engineering analysis to determine what seismic upgrading should be completed to ensure adequate performance.

The San Francisco Freeway Viaducts are of substantially comparable design and construction to those of the Cypress Viaduct and could be expected to suffer severe damage and possibly collapse if they were subjected to more intense ground motions or ground motions of longer duration. The installation of cable restraints under the Caltrans seismic 
retrofit program appears to have improved their behavior, possibly saving some spans from collapse by limiting the relative displacements of the decks at the expansion joints.

The repair of some of the San Francisco Freeway Viaducts is already underway. The retrofitting is expected to substantially strengthen the columns, but the precise degree of improvement in seismic resistance of the structures will not be clear without detailed studies and analyses The Board is unable to evaluate the specific details of the retrofit designs and programs for the individual viaducts. It considers them to be only short-term approaches to their repair.

Substantially more engineering analysis and evaluation will be required to determine if additional seismic retrofitting may be appropriate for the Bay Bridge and San Francisco Freeway Viaducts to be appropriately safe in the long-term.

\section{Should the State modify the existing construction or retrofit programs for freeway structures and bridges in light of new information gained from this earthquake?}

Yes.

This earthquake has demonstrated the fact that nonductile structures designed prior to 1971 can fail in a brittle manner with consequent collapse. It also emphasized that the intensity of ground shaking on soft soils may be greater than is anticipated by current seismic codes. This evidence therefore requires modifications to both the retrofit program and to new design standards, as contained in the Recommendations and Findings of this Report. Caltrans appears to be vigorously modifying their technical approaches and standards for each.

The existing State-wide Caltrans seismic retrofit program should continue to consider the overall behavior of transportation structures and foundations and not be principally focused on the behavior of structural elements. It should be enhanced by the assignment of greater personnel and budgetary resources so that the retrofit program can be implemented and completed within this decade.

Most of California's reinforced concrete bridges were designed and built before the 1970s and many are deficient in their earthquake resistance. This was caused by the slow development through research of new knowledge in earthquake engineering for bridge design and the usual lag in putting research results into practice. The quality, effectiveness and economy of new construction and seismic upgrading will be enhanced substantially if a vigorous research program is undertaken on earthquake engineering, as opposed to the limited and occasional efforts of the past.

The fiscal environment at Caltrans in the past 20 years inhibited Caltrans from giving more attention to seismic problems. This environment has improved following the Loma Prieta earthquake. Increased attention, funds and personnel resources are being devoted to earthquake safety.

\section{Are California's freeways earthquake-safe?}

Most are, but some are not.

Among the more than 11,000 structures in the State highway system there are some that have the potential for severe damage and collapse in the event of a worst-case earthquake. These warrant prompt, systematic correction, but the Board of Inquiry is not aware of any that warrant closure, based on the Board's understanding of past Caltrans seismic design and 
construction practices. The occasional earthquake life-safety risks posed by highway structures is different than those continuously posed by traffic conditions. Earthquakes large enough to pose a threat have relatively low probability of occurring at a given location.

The Board thinks existing high hazard structures can and should be corrected in a planned and accelerated program. With the implementation of the Board's Recommendations, Caltrans can complete the identification of these structures and carry out the required seismic retrofitting. Then the freeway structures will be appropriately safe.

\section{CONCLUSIONS}

The Loma Prieta earthquake was a clear and powerful warning to the people of California. Fortunate it occurred in a sparsely populated region near a major urban center, not within its confines where the consequences would have much greater. Although progress has been made during the past two decades in reducing earthquake risks, much more could have been done. More aggressive efforts to mitigate the consequences of earthquakes are needed if their potential is to be minimized.

Those institutions, both public and private, who do not want to be confronted by the problems faced by Caltrans after this earthquake should note that Caltrans is a management and engineering organization of great skill and dedication. The condition that lead to the observed unacceptable performance of bridges was part the result of the lack of a specific seismic safety policy within the organization, part an insular attitude of looking almost solely within for technical content and guidance, and part a failing to appreciate the benefits of independent evaluation of technical practices and designs. In addition, there was a critical gap in the knowledge required to effectively mitigate earthquake hazards and there were delays in incorporating such knowledge into practice.

Caltrans did not have a management-directed seismic safety performance goal that must be met by all its structures. The requirements of accommodating earthquakes were contained in design documents for use by engineers on individual projects, rather than as policy guidance requirements from the management of Caltrans or from the Legislature. It is common for construction projects to have many criteria and constraints, all of which cannot be simultaneously met, particularly within budget and on time. The pressures of relieving traffic congestion and the limitations on funds led to severe budgetary problems for Caltrans. The 17year period to implement the modest-cost cable restrainer program after the 1971 San Fernando earthquake suggests that seismic safety was not as pressing as other issues. It is natural that seismic requirements, when not specifically stated as part of policy, can become the subject of compromises as management makes allocations among competing uses for limited funds. Internal design guidance does not provide the same level of assurance of good seismic policies and practices as does a clear statement of minimum seismic safety goals for an organization, especially when there is no independent review.

An important lesson to be learned from this earthquake is that independent, technical review is essential to achieve consistent excellence in civil engineering design and construction. The process of design of structures is still one that entails the making of many decisions and technical compromises. A peer review should be conducted if the owner/client wants assurance that a project design of acceptable quality will be received.

Another lesson to be learned from the Loma Prieta Earthquake is that over the years improvements are made in seismic design. These result from research, from study of earthquake damage, improvements in materials, etc. As a consequence, structures that were designed within the understanding of a previous time may not meet modern standards of 
seismic safety. Such potentially hazardous structures should be identified and strengthened. It is especially important that this be done for major structures whose collapse would threaten many lives or would have a severe impact on the functioning of a community.

Future earthquakes are inevitable-in California and the nation. They represent a continuing danger to our population and economy. The consequences of severe earthquakes in urban areas will be extensive-too large for "business as usual." It is time to set priorities for seismic safety. Research and development must be supported to meet our needs for effective, economic strategies for earthquake hazards mitigation, and determined actions must be taken to reduce seismic risks.

\section{REFERENCES}

[1] Executive Department, State of California, Executive Order D-86-90, June, 1990.

[2] Executive Department, State of California, Executive Order D-83-89, November, 1990.

[3] Board of Inquiry on the 1989 Loma Prieta Earthquake, George W. Housner, Chairman. Competing Against Time. Report to the Governor, The State of California, Office of Planning and Research, Sacramento, California, May, 1990.

[4] Loma Prieta Earthquake Reconnaissance Report, Earthquake Spectra, supplement to Volume 6, May, 1990.

[5] Working Group on California Earthquake Probabilities. "Probabilities of Large Earthquakes Occurring in California on the San Andreas Fault." Geological Survey Open-File Report 88-398, United States Department of the Interior, U. S. Geological Survey, United States Government Printing Office, 1988

[6] Scott, Mel. The San Francisco Bay Area. University of California Press, Berkeley, California, 1985.

[7] Diridon, Rod, Chairman, Metropolitan Transportation Commission. "Year 2005 Bay Area Travel Forecasts, Technical Summary." Metropolitan Transportation Commission, 1988.

[8] Davis, James F., John H. Bennett, Glenn A. Borchardt, James E. Kahle, Salem J. Rice, and Michael A. Silva. "Earthquake Planning Scenario for a Magnitude 8.3 Earthquake on the San Andreas Fault in the San Francisco Bay Area." Special Publication 61, California Department of Conservation, Division of Mines and Geology, 1982

[9] Steinbrugge, Karl V., John H. Bennett, Henry J. Lagorio, James F. Davis, Glenn Borchardt, and Tousson R. Toppozada. "Earthquake Planning Scenario for a Magnitude 7.5 Earthquake on the Hayward Fault in the San Francisco Bay Area." Special Publication 78, California Department of Conservation, Division of Mines and Geology, 1987

[10] Nims, D. K., E. Miranda, I. D. Aiken, A. S. Whittaker, and V. V. Bertero. "Collapse of the Cypress Street Viaduct as a Result of the Loma Prieta Earthquake." Report No. UCB/EERC-89/16, University of California, Berkeley, November 1989 


\section{APPENDIX FINDINGS}

Central to the Board's process has been the determination of what occurred during the earthquake and why. These findings formed the basis for the recommendations made by the Board of Inquiry. The fifty-two specific findings of the Board are organized under the following general headings:

1. Findings on seismology and ground motion

2. General findings on transportation structures

3. Findings on Caltrans seismic design practices

4. Findings on the Bay Bridge failure

5. Findings on the Cypress Viaduct collapse

6. Findings on San Francisco Freeway Viaducts

7. Findings on the Caltrans retrofit program

8. Findings for other types of structures

The full report, Competing Against Time, [3], presents a discussion that gives the rationale for each finding and the technical information on which they were based.

\section{Findings on Seismology and Ground Motion}

1 The Loma Prieta earthquake was a Magnitude 7.1 earthquake with epicenter in the Santa Cruz Mountains over 60 miles from San Francisco and Oakland, 20 miles from San Jose, and 10 miles from Santa Cruz. The epicenter and region of strongest ground shaking was in a sparsely populated, mountainous area. Its ground motions were far from the most severe that can be expected as seismic dynamic loadings for bridges, either in the Bay Area or the State.

2 The Loma Prieta earthquake was anticipated by the Working Group on California Earthquake Probabilities, but not with high enough probability of occurrence (30\% in the next 30 years) or confidence in the forecast (low) to have caused Caltrans or others to respond directly to this forecast.

3 The duration of the strong phase of ground shaking generated by the Loma Prieta earthquake was unusually short for an earthquake of Magnitude 7.1.

4 Soft ground on the border of the San Francisco Bay amplified ground motions more than anticipated by current codes.

5 Soil liquefaction was observed in the region, but there is no evidence that it contributed to the Cypress Viaduct or Bay Bridge span failures.

\section{General Findings on Transportation Structures}

6 In addition to the tragic loss of life, the economic and social consequences of the Cypress Viaduct collapse and the Bay Bridge span collapse outweighed the costs of the damage itself.

7 The available knowledge, seismic codes, and standards of practice of earthquake engineering have changed substantially from that of the periods when the Cypress Viaduct (early 1950s) and San Francisco-Oakland Bay Bridge (early 1930s) were designed and constructed.

8 Historically, the fiscal environment at Caltrans has inhibited giving the level of attention to seismic problems at the level required.

9 The Board finds that Caltrans has the reputation of being the best transportation agency among the States and a leader in bridge design.

10 No comprehensive analyses of the expected seismic performance of major transportation structures (e.g., Bay Bridge, Golden Gate Bridge, BART Trans-bay Tube) have been completed, since their design, by the authorities responsible for them. 
11 Current federal criteria, when used for California transportation projects, may not be sufficiently conservative and inclusive of seismic concerns to meet the seismic safety needs of the State of California.

12 There was no seismic instrumentation on the Bay Bridge, Cypress Viaduct, San Francisco Freeway Viaducts, or BART Trans-bay Tube. Only a few transportation structures were instrumented. This severely limits information on what the ground motions were and how the structures responded to these motions.

\section{Findings on Caltrans Seismic Design Practices}

13 Caltrans does not have a management-directed seismic safety performance goal that must be met by all its structures.

14 Caltrans and the American Association of State Highway and Transportation Officials (AASHTO) seismic design codes had very low seismic requirements at the time of design of the Cypress Viaduct and the San Francisco Freeway Viaducts, both in comparison to those for buildings as specified by the Uniform Building Code of the same period and to current Caltrans requirements.

15 Caltrans bridge seismic design codes have improved substantially since the 1971 San Fernando earthquake, but have not been subjected to independent review.

16 The basis for seismic design of Caltrans bridges before the Loma Prieta earthquake was that damage is acceptable as long as collapse is prevented. After the earthquake, the objective was modified to add that important structures will require only limited repair following major earthquakes.

17 Subsurface information customarily was not obtained by Caltrans in sufficient detail to enable a careful evaluation to be made of seismic loading conditions on foundations and the effects of soil-structure interaction.

18 Most Caltrans concrete structures are of an age that they have nonductile detailing. Therefore, it should have been assumed by Caltrans that these were all at varying degrees of risk of earthquake failure.

19 Many structures have been built that are deficient in their earthquake resistance. This has been caused by the slow development of new knowledge through limited research in earthquake engineering bridge design and the lag in putting research results into practice.

20 Caltrans has implemented a number of actions to improve seismic design, including an independent review process for major projects.

\section{Findings on Bay Bridge Failure}

21 The 50-foot-long upper and lower closure spans of the Bay Bridge over Pier E9 fell when the bolts failed that connected the pier with the $290^{\prime}$ truss-span to the east. Another span at pier E23, close to the eastern edge of the bridge, was near failure of a comparable type.

22 The Bay Bridge was designed for $10 \%$ g earthquake accelerations, comparable to the levels specified in the 1930 Uniform Building Code for buildings.

23 The Bay Bridge appears to have no design or construction deficiencies as measured by the practices at the time it was built. There is no indication of subsequent maintenance deficiencies that contributed to failure of the span.

24 Although some seismic structural rehabilitation had been completed on the Bay Bridge, there is no evidence that Caltrans was especially concerned about the earthquake collapse hazards posed by the Bay Bridge.

25 There is no evidence that foundation failure contributed to the failure of the Bay Bridge span.

26 Given that the truss-to-pier connections on the east side of Pier E9 failed, the closure span would be considered in jeopardy of collapsing.

27 The structural steps taken to repair the Bay Bridge appear to be appropriate for the short-term. 
28 No engineering assessment of the dynamic, seismic performance of the Bay Bridge has ever been made.

29 The Bay Bridge may not be presumed to be adequately earthquake resistant just because it was only slightly damaged during the Loma Prieta earthquake and has since been repaired.

\section{Findings on Cypress Viaduct Collapse}

30 The Cypress Viaduct was designed and constructed to Caltrans seismic practices for reinforced concrete when built in the 1950s. It, and the San Francisco Freeway Viaducts, are brittle structures, possessing very little ductility, which was consistent with practices of the period.

31 The Cypress Viaduct appears to have been constructed according to plans and specifications with good quality materials and workmanship. There is no evidence of maintenance problems since construction that would affect its earthquake performance. The modifications to provide cable restrainers at the expansion joints appear to have been designed and installed to Caltrans specifications.

32 The Board is not aware of any evidence suggesting that Caltrans was specifically aware of the earthquake collapse hazards posed by the Cypress Viaduct.

33 No evidence was presented to the Board that the foundation failed or that foundation problems contributed to the Cypress Viaduct collapse.

34 The Board concludes that a modern engineering seismic assessment of the Cypress Viaduct conducted before the earthquake, performed by a professional engineering organization in a manner consistent with the care and expertise usually exercised in evaluating such important structures, would have concluded that a collapse potential existed. Specifically, such an assessment would probably have concluded that:

A The Cypress Viaduct would collapse in a nearby major earthquake on the San Andreas or Hayward faults.

B An earthquake with Loma Prieta's Magnitude and location would probably not cause collapse, but would cause concern because of the weak, brittle nature of the structure.

C Collapse would have been anticipated for the intensity of ground motion that did occur at the Cypress Viaduct site in the Loma Prieta earthquake, however, the extent of the collapse would probably not have been anticipated.

35 The demolition of a section of the standing Cypress Viaduct was very instructive and demonstrated the extent of collapse possible once local failure of a column or bent has occurred.

36 Tests indicate that retrofitting of the Cypress Viaduct columns and joints could have increased the seismic resistance of these elements.

\section{Findings on San Francisco Freeway Viaducts}

37 The San Francisco Freeway Viaducts are similar in design and construction to the Cypress Viaduct.

38 The San Francisco Freeway Viaducts could be expected to suffer more severe damage and possibly collapse, if they had been subjected to the intensity of ground motions experienced by the Cypress Viaduct.

39 The Caltrans repair and seismic retrofit of the San Francisco Freeway Viaducts is already underway. The retrofitting is expected to increase substantially the strength of the columns, but the precise degree of improvement in seismic resistance of the structures from these retrofits is not clear to the Board. The Board was unable to evaluate the specific details of the retrofit designs and programs for the individual viaducts in the time available, and considers them to be only short-term approaches. 


\section{Findings on Retrofit Program}

40 Caltrans has over 11,000 State-owned bridges within its jurisdiction, most of which were designed before basic understanding of earthquake engineering design was developed.

41 Caltrans instituted a seismic retrofit program in 1971 that, over the next 17 years, installed cable restrainers at expansion joints in over 1,200. Such restrainers are not generally sufficient to prevent collapse under strong earthquake shaking.

42 The installation of cable restrainers under the Caltrans seismic retrofit program did not contribute to initiation of the collapse of the Cypress Viaduct. The precise influence of the cables on the failure process is not clear. The cable restrainers appear to have improved the behavior of San Francisco Freeway Viaducts, possibly saving some spans from collapse by limiting the relative displacements of the decks at the expansion joints.

43 Caltrans began a second phase of seismic retrofitting following the 1987 Whittier Narrows earthquake in response to the near collapse of the I-605/I-5 overcrossing. This program was aimed primarily at strengthening single column bents of elevated structures and did not include the Cypress Viaduct.

44 Cities and counties within the State have responsibility for approximately 11,000 bridges and use the same criteria for design as Caltrans when federal or State funds are involved; their bridges can be expected to have the same seismic problems as those of the State.

45 An evaluation of the current Caltrans seismic retrofit program indicated that:

A The cable restrainer retrofit program addressed the first order failure mode for bridges, as identified in the 1971 San Fernando earthquake, and appears to have been an effective short-term, low-budget approach to improving the seismic performance of Caltrans bridges in relation to some, but not all aspects of response.

B The single column reinforcement program appears to be reasonable for the shortterm, if adequately planned and implemented in a timely manner.

C The remaining retrofit program, currently being planned, will address the problem of multiple column bents and all bridges State-wide, and also appears to be reasonable for the short-term.

D The complex response of bridges to earthquakes makes it unclear what specific retrofit program is best in the long-term, either from a budgetary or seismic safety standpoint. It is clear that consideration of the entire structure, foundations and supporting soils is necessary to assess a retrofit approach.

46 There are no widely accepted technical standards for seismic retrofit of bridges.

\section{Findings For Other Types of Structures}

47 A substantial number of California buildings and facilities are deficient in seismic resistance as measured by current standards. The fact that a particular type of structure has not yet been damaged in earthquakes does not necessarily indicate that its earthquake resistance is adequate.

48 Independent, technical review is essential to achieve consistent excellence in civil engineering design and construction.

49 The registration of professional engineers with a specialty in bridge design is not warranted.

50 Loss of life from and damage to currently existing substandard structures will dominate the impacts suffered in future California earthquakes.

51 Many structures are not subject to seismic codes or to review by an independent third party before construction.

52 Many State-owned structures are seismically substandard and many known hazardous conditions have not been addressed. 